\title{
A new era for the Science and Technology Development Journal
}

\author{
Phuc Van Pham ${ }^{1,2}$,
}

${ }^{1}$ Science and Technology Development Journal, Viet Nam National University Ho Chi Minh City, Viet Nam

${ }^{2}$ VNUHCM University of Science, Ho Chi Minh, Viet Nam

\section{Correspondence}

Phuc Van Pham, Science and Technology Development Journal, Viet Nam National University Ho Chi Minh City, Viet Nam

VNUHCM University of Science, Ho Chi Minh, Viet Nam

Email: pvphuc@vnuhcm.edu.vn

\section{History}

- Received: 20 April 2018

- Accepted: 25 April 2018

- Published: 28 April 2018

DOI : 10.32508/stdj.v21i1.425

\section{Check for updates}

\section{Copyright}

(c) VNU-HCM Press. This is an openaccess article distributed under the terms of the Creative Commons Attribution 4.0 International license.

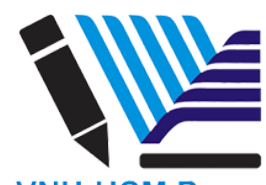

VNU-HCM Press
The Science and Technology Development Journal (STDJ) is the official scientific publication of the Viet Nam National University Ho Chi Minh City, Viet Nam (VNUHCM). The STDJ was firstly published in 1998 to aim push the publication activities of students, researchers, and scientists of VNUHCM. Since then, STDJ has become the most important scientific forum of scientists from VNU-HCM as well as other universities. The journal has undergone 20 years of development and has become a bridge for scientific exchanges, as well as enriching reference materials for the faculty, doctoral students, students of VNU-HCM in particular and other universities, institutes... By the end of 2017, the journal has published 296 issues with about 3000 articles in five areas of research: Engineering and Technology, Natural Sciences, Social Sciences and Humanities, Economics of Law and Management Sciences, Earth Sciences and Environment.

Thanks to the efforts of the earlier editorial team, the journal continued to serve as a major source for research to help a lot of researchers to exchange and communicate their works with the scientific communities.

To increase the international audiences and become the international peer-reviewed journal, STDJ will be published full-texts in English from Vol 21 (2018). The journal currently consists of the following six sections:

- Engineering and Technology,

- Natural Sciences,

- Social Sciences and Humanities,

- Law, Economy and Management,

- Earth and Environmental Sciences,

- Health Sciences

Now, thanks to the efforts of the new editorial team and the continued support of the Viet Nam National University Ho Chi Minh City and the sponsors of
Ministry of Science and Technology, the STDJ becomes an international peer-reviewed journal. STDJ was already indexed in Google Scholar, and plans to be indexed in Asean Citation Index, OpenJGate, ProQuest, SCOLOAR, Summon by Serial Solutions, Ulrich's International Periodical Directory Index Corpenicus, DOAJ, EBSCO Publishing's Electronic Databases, Scopus, and Web of Science in the near future.

From 2018, the journal has new open website at http //www.stdj.scienceandtechnology.com.vn with more than 3000 articles from 1998. STDJ also has new editorial team, editorial board, and advisory board that continue to push the STDJ to become the international science journal in the new era.

We would like to thank the former editors-in-chief, Professor Nguyen Ngoc Giao (1998-2005) for establishing the STDJ, and to Professor Phan Thanh Binh (2006-2016) and Professor Duong Anh Duc (October 2016-April 2018) for keeping up the good work. STDJ is also grateful to thank all former members of the previous editorial boards, advisory boards, and reviewers, authors and readers for their input, which kept the STDJ alive.

We are looking forward to a bright future of STDJ.

Phuc Van Pham, Journal Manager

Science and Technology Development Journal, Viet Nam National University Ho Chi Minh City

\section{OPEN ACCESS}

This article is distributed under the terms of the Creative Commons Attribution License (CC-BY 4.0) which permits any use, distribution, and reproduction in any medium, provided the original author(s) and the source are credited.

\section{COMPETING INTERESTS}

The authors declare that there is no conflict of interest.

Scan to download the article

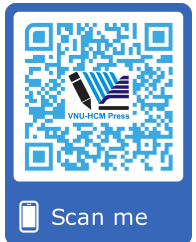

Cite this article: Pham P V. A new era for the Science and Technology Development Journal . Sci. Tech. Dev. J.; 21(1):1-1. 